\title{
Nutrition, Metabolic Status and Reproductive Efficiency in Dairy Herds
}

\author{
György Gábor1*, Orsolya Gabriella Balogh11, László Kern1', Petra Réka Gábor², \\ Hedvig Fébel ${ }^{1}$ \\ ${ }^{1}$ National Agricultural Research Institute-Research Institute for Animal Breeding, Nutrition and Meat Science, \\ Herceghalom, Hungary \\ ${ }^{2}$ AndrovetKft, Budapest, Hungary \\ Email: "h12617gab@helka.iif.hu
}

Received 5 November 2015; accepted 17 January 2016; published 20 January 2016

Copyright (C) 2016 by authors and Scientific Research Publishing Inc.

This work is licensed under the Creative Commons Attribution International License (CC BY).

http://creativecommons.org/licenses/by/4.0/

(c) (i) Open Access

\section{Abstract}

Nutrition of transition period in dairy cows dramatically increases requirements for energy, glucose, amino acids and other nutrients in dairy cows and, parallel to that, feed intake is depressed. An insufficient or imbalanced nutrient intake might lead to the malfunction of organs, causing reproductive failure. To minimize the metabolic/reproductive damage caused by negative energy balance (NEBAL), feeding of a glucogenic and lipogenic diet containing fat-enriched supplements is recommended. In heat-stressed dairy cows, the reduction of dry matter intake causes an energy deficit, thereby accentuating NEBAL. Heat stress may also have a direct impact on oocyte quality due to the high ovarian temperatures. The intrauterine environment is also compromised in heatstressed cows, with reduced blood flow to the uterus and increased uterine temperature; this may impair embryonic development, increase early embryonic loss and reduce the proportion of successful inseminations. Postpartum NEBAL suppresses immune function and promotes metabolic disorders, potentially explaining relationships between infectious and noninfectious transition disorders. In postpartum dairy cows, pathologic ovarian phenomena including ovulatory (cystic corpora lutea) and non-ovulatory (follicular and luteal cysts) forms frequently occur causing decreased fertility. The main objective of this review was summarizing the most relevant information regarding nutrition and reproduction in dairy cows.

\section{Keywords}

Dairy Cattle, Reproduction, Nutrition, Metabolic Status

\footnotetext{
${ }^{*}$ Corresponding author.
} 


\section{Introduction}

Efficient reproduction in dairy cattle herds is of great economic importance. Increased milk production together with suboptimal farm management (especially nutrition or reproduction) can reduce fertility. Over the past decades, the calving interval has increased in parallel with milk production in several countries including the US and Hungary (Table 1 and Figure 1 ).

Extreme selection pressure for milk production in dairy cows has been highly successful. Unfortunately, there are clear negative correlations between milk yield and fertility, presence of mastitis, and other health traits. The decline in fertility is of multifactorial origin and not exclusively associated with increased milk production. To improve the decreased fertility, cow longevity, health and fertility have been used as selection criteria in many breeding programs in numerous countries [4]. Factors such as management and husbandry, nutrition and reproductive diseases determine reproductive performance (number of open days, calving interval, number of AI per pregnancy, pregnancy rate, and early/late embryonic loss). Over the past few years, several trials have been conducted to determine the effect of a more economical dry period length [5] on the postpartum health [6], production [7] [8], and reproduction [9] [10] of dairy cows.

\section{Nutrient Intake, Metabolic and Hormonal Status and Reproductive Failures}

The major problem in postpartum cows is the imbalance between the body reserves and milk production. The transition (late pregnancy to early lactation) period dramatically increases requirements for energy, glucose, amino acids and other nutrients in dairy cows and, parallel to that, feed intake is depressed. This is why a negative energy balance (NEBAL) occurs in the background of reduced fertility (Figure 2).

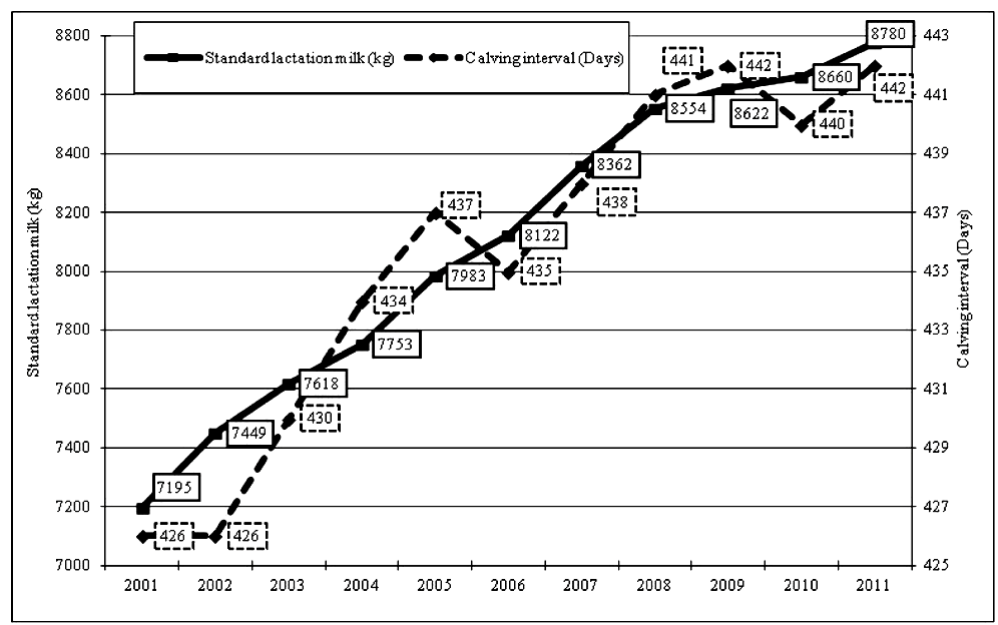

Figure 1. Changes of milk production and calving interval in Hungary between 2001 and 2011 [3].

Table 1. Change of the calving interval (days) in the Holstein breed in the US.

\begin{tabular}{ccc}
\hline Parity & Nieuwhof et al., $1989[1]$ & Hare et al., 2006 [2] \\
\hline 1 & 394.2 & 402.9 \\
2 & 392.8 & 402.4 \\
3 & 394.6 & 403.4 \\
4 & 398.1 & 406.2 \\
5 & 400.4 & 408.9 \\
6 & 404.7 & 410.8 \\
7 & & 412.9 \\
\hline
\end{tabular}


Since the transition period involves the most important physiological changes of the time around calving, it is a favorable target for reproduction and nutrition physiologists. Both calving and the start of milking act as stress factors for cows, influencing metabolic and hormonal changes (Figure 3). An insufficient or imbalanced nutrient intake might lead to the malfunction of organs (liver, hypothalamus, hypophysis, ovary, uterus), causing reproductive failure.

\section{Calving and Immune Function}

It is estimated that approximately $30 \%$ - 50\% of cows are affected by some form of metabolic and/or infectious diseases in the periparturient period. Calving itself represents a major oxidative stress for cows. Oxidative stress is an imbalance between radical-generating and radical-scavenging activity, resulting in oxidation products and tissue damage. The production of free radicals and reactive metabolites is one of the basic mechanisms underlying reproductive diseases, and antioxidant status is a major determinant of reproductive function in farm animals [11].

Calving disorders have a strong influence on the postpartum period. Retained fetal membranes (RFM) and puerperal metritis are more frequent when calving is assisted. During the postpartum period, rapid and uneventful involution of the uterus, early resumption of normal ovarian activity, and accurately detected estrus are re-

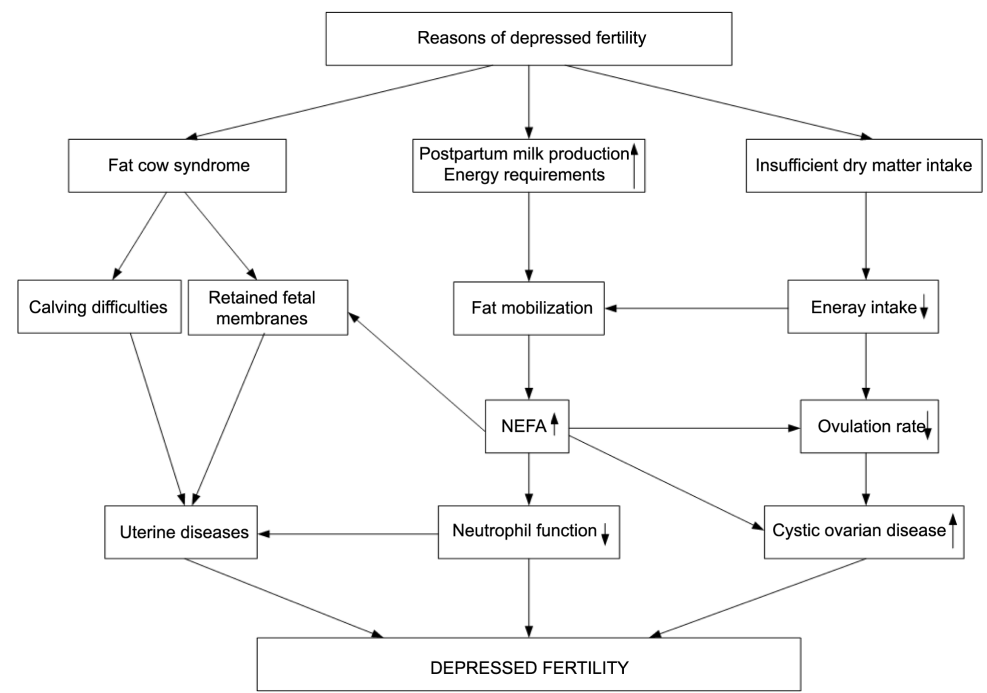

Figure 2. Most common causes of depressed fertility.

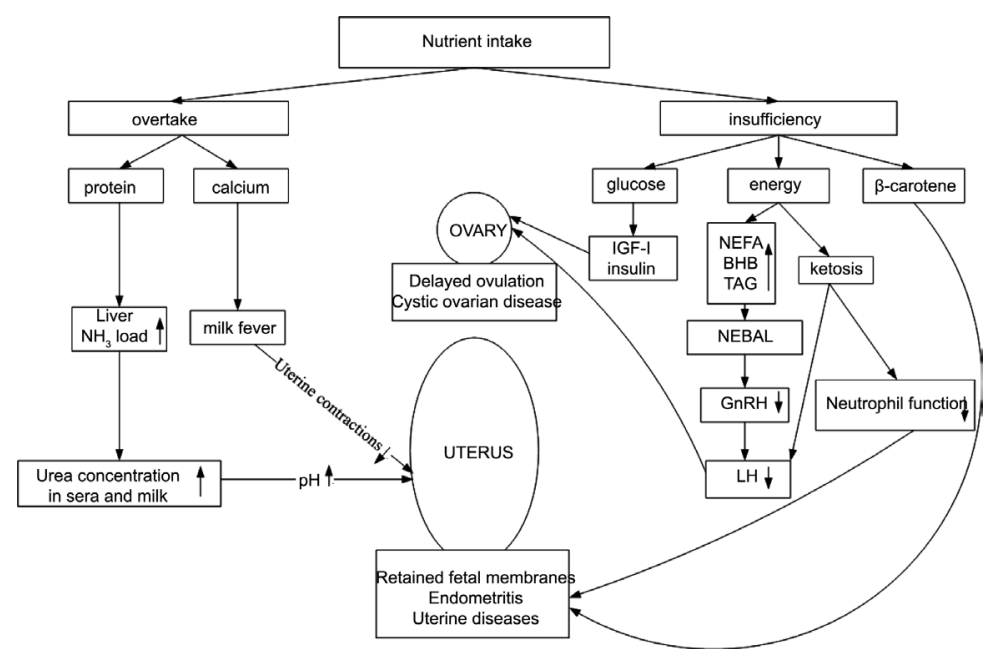

Figure 3. Effect of possible nutritional factors on ovaries and uterus in the transition period. 
quired. Most cows develop a mild non-pathological endometritis during the early puerperal phase. This physiological condition, together with reduced immunocompetence due to high milk production, NEBAL and poor calving hygiene, can cause puerperal endometritis [12]. Metritis causes endometrial damage, which can delay conception.

\section{Different Dietary Solutions for the Prevention of Metabolic Imbalance and Reproductive Disorders}

To minimize the metabolic/reproductive damage caused by NEBAL, feeding of a glucogenic and lipogenic diet containing fat-enriched supplements is recommended [12]. This issue has been the focus of an extremely high number of studies, which sometimes brought contradictory results (Table 2).

Gluconeogenic materials (propylene glycol, glycerol, propionic acid) are precursors of glucose in the liver and increase glucose concentration of the serum. Elevated serum glucose concentration results in decreased fat mobilization (lower energy demand and increased insulin level), and indirectly improves reproductive efficiency. Gluconeogenic feed additives are thought to exert their favorable effect through the stimulation of insulin secretion [27].

Propylene glycol seems to be the most effective gluconeogenic substance, as it was found to decrease the plasma non-esterified fatty acid (NEFA) and beta-hydroxybutyrate (BHB) levels and increase the blood insulin and glucose concentrations in several experiments. Propylene glycol and its metabolites (lactate, pyruvate) directly stimulate insulin secretion [28].

Glycerol supplementation seems to have moderate metabolic effects: it did not modify plasma glucose, insulin, NEFA and BHB levels [29]. However, in another trial [30] 1 kg glycerol applied as a drench increased plasma

Table 2. Literature review of the effect of dietary gluconeogenic and fat supplementation on reproductive efficiency.

\begin{tabular}{|c|c|c|c|}
\hline Nutritional factor & Product & References & Comment \\
\hline \multirow[t]{8}{*}{$\begin{array}{l}\text { Gluconeogenic feed } \\
\text { additives }\end{array}$} & Propylene glycol (PGL) & {$[13]$} & $\begin{array}{l}\text { Despite evidence of improved metabolic status, } \\
\text { PGL failed to increase LH pulse frequency, } \\
\text { and failed to increase the proportion of first } \\
\text { postpartum follicle waves resulting in ovulation }\end{array}$ \\
\hline & & {$[14]$} & $\begin{array}{c}\text { Reduced interval from calving to first ovulation } \\
\text { was observed and pulsatile release of LH at } 2 \text { and } \\
5 \text { weeks was greater in cows fed PGL }\end{array}$ \\
\hline & & {$[15]$} & $\begin{array}{l}\text { Cows fed PGL commenced ovarian } \\
\text { cyclicity earlier than controls }\end{array}$ \\
\hline & & {$[16]$} & $\begin{array}{l}\text { Improved conception rate (33 to 57\%) and day } \\
\text { of first ovulation from 44.5 Day to } 32.3 \text { Day }\end{array}$ \\
\hline & PGL + Ca-propionate & {$[17]$} & $\begin{array}{l}\text { Treatment did not change the proportion of } \\
\text { puerperal diseases and reproductive performance }\end{array}$ \\
\hline & Glycerol & {$[18]$} & No effect on DMI, glucose $\uparrow$, NEFA and BHB $\downarrow$ \\
\hline & & {$[19]$} & Conception rate and insulin cc. $\uparrow$ \\
\hline & Propionate salts & {$[20]$} & Improves reproductive efficiency \\
\hline \multirow[t]{6}{*}{ Fat supplementation } & Ca-long chain fatty acid (LCFA) & {$[21]$} & Pregnancy rate per AI increased from $35.5 \%$ to $51.1 \%$ \\
\hline & Fish oil & {$[22]$} & Reduced PGFM \\
\hline & Ca-LCFA of palm oil & [23] & $\begin{array}{c}\text { From cows fed } 800 \mathrm{~g} \text { fat/day a higher percentage } \\
\text { of oocytes developed into blastocysts }\end{array}$ \\
\hline & $\begin{array}{l}\text { Soybean oil refining by-products } \\
\text { (SORB) }\end{array}$ & [24] & $\begin{array}{l}\text { Loss of body condition was less and first ovulation } \\
\text { was experienced earlier in cows fed SORB }\end{array}$ \\
\hline & $\begin{array}{l}\text { Saturated fatty acid (FA), } \\
\text { Ca-salts of t-octadecanoic FA, } \\
\text { Ca-salts of safflower oil FA }\end{array}$ & [25] & $\begin{array}{l}\text { Mean concentrations of glucose, IGF-1 and P4 were } \\
\text { higher in cows fed a safflower oil enriched diet }\end{array}$ \\
\hline & $\begin{array}{c}\text { Ca salts of palm oil, Ca salts of } \\
\text { safflower oil (SO) and fish oil (FO) }\end{array}$ & [26] & $\begin{array}{l}\text { Overall pregnancy rate per AI was higher in cows fed an } \\
\text { SO diet and pregnancy loss was reduced in FO-fed cows }\end{array}$ \\
\hline
\end{tabular}


glucose and insulin and decreased plasma NEFA concentration.

The sometimes contradictory results can be attributed to the different experimental conditions (e.g. dosage, duration and method of, application, lactation period, level of NEBAL, and certainly the body condition of cows).

The feed intake of cows is lower in early lactation, and therefore dietary fat supplementation in the early postpartum period alters energy status even though a more energy dense ration is fed. Increasing the caloric density of the ration by fat feeding might improve the reproductive parameters of cows. Improvement of the energy status of dairy cows has been found to influence reproduction by increasing the frequency of LH pulses [31], modulating the number of larger follicles, altering the size of the dominant follicle, and increasing progesterone concentrations during the luteal phase of the estrous cycle [32]. Supplemental fat improves ovarian follicular dynamics, which is in a positive correlation with pregnancy rate [33] [34]. The use of fat in dairy cow diets usually increases the energy density of the ration and improves reproduction; however, these effects might be mediated by the fatty acid (FA) composition of the fat source. Polyunsaturated fatty acids (PUFA) can influence different levels of the hypothalamo-pituitary-ovarian axis, and they can locally stimulate follicular growth by altering hormone and metabolite levels. Fatty acids are precursors for ovarian steroidogenesis and for the synthesis of endometrial eicosanoids $\left(\mathrm{PGF}_{2 \alpha}, \mathrm{PGE}_{2}\right)$. Different PUFAs are important mediators of uterine involution and the ovulatory processes. Feeding sunflower oil rich in linoleic acid (C18:2, n-6) promotes uterine involution. Supplementation of linseed ( $\alpha$-linolenic acid, C18:3, n-3) or the feeding of fish oil containing a high amount of eicosapentaenoic acid (C20:5, n-3) and docosahexaenoic acid (C22:6, n-3) may inhibit endometrial PGF $2 \alpha$ synthesis through mechanisms such as the decreased availability of its precursor, arachidonic acid. PUFAs of the n-3 family suppress luteolytic signals around the maternal recognition of pregnancy. This might improve the mechanism of embryo preservation and support embryonic survival in cattle.

The natural defense of postpartum cows is based on both cellular and humoral (local) immunity. An increased level of antioxidants should prevent the depression of neutrophil function caused by free radicals in the postpartum period. It was found that adequate beta-carotene supplementation significantly reduced the incidence of RFM and metritis [35]. Administration of vitamin E and/or selenium has been reported to reduce the incidence of postpartum reproductive disorders such as RFM, metritis and cystic ovaries, and improved fertility in cattle. Circulating NEFA and BHB are known to have a direct negative effect on neutrophil function.

\section{Environmental Factors Influencing Fertility through Metabolic Imbalance}

Since 2002, two databases [Catus: ultrasound examinations of the cow's reproductive tract; Bopella: laboratory examination of pregnancy and late embryonic loss by pregnancy-specific protein B (PSPB) and P4 ELISA tests] have been developed in our institute for recording the metabolic and reproductive data of dairy herds (Figure 4). These databases provide an opportunity for analyzing relationships between the results of ultrasonic, endocrine and metabolic measurements.

\subsection{Effect of Ambient Temperature on Postpartum Reproductive Performance}

Extremely high ambient temperature may cause heat stress, which considerably impacts production and reproduction in dairy cattle. In heat-stressed dairy cows, the reduction of dry matter intake causes an energy deficit, thereby accentuating NEBAL. In addition, reduced rumination and/or absorption of nutrients together with increased maintenance requirements also result in a net decrease of dry material/energy intake. Heat stress may also have a direct impact on oocyte quality due to the high ovarian temperatures. The intrauterine environment is also compromised in heat-stressed cows, with reduced blood flow to the uterus and increased uterine temperature; this may impair embryonic development, increase early embryonic loss and reduce the proportion of successful inseminations. During the hot summer period, poor expression of estrus, a rapid decrease in pregnancy rate and a pronounced increase of late embryonic loss (LEL) are common.

Based on the assessment of 68,000 samples for serum pregnancy PSPB concentration and re-checking the pregnant cows by transrectal palpation, the rate of pregnant samples (RPS) decreased while LEL increased (Figure 5) parallel to the rise of daily average temperature [36].

\subsection{Effect of Ambient Temperature on Metabolic Status}

The mean plasma NEFA and BHB concentrations were significantly higher (Figure 6 and Figure 7), while se- 

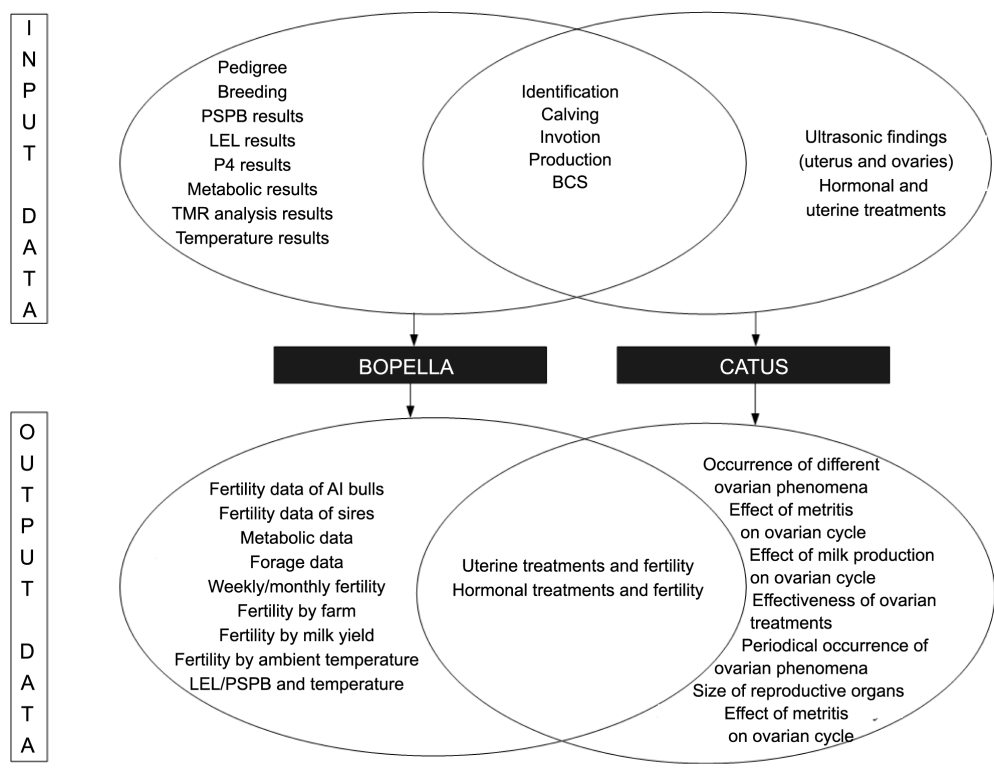

Figure 4. Structure of Bopella and Catus databases.

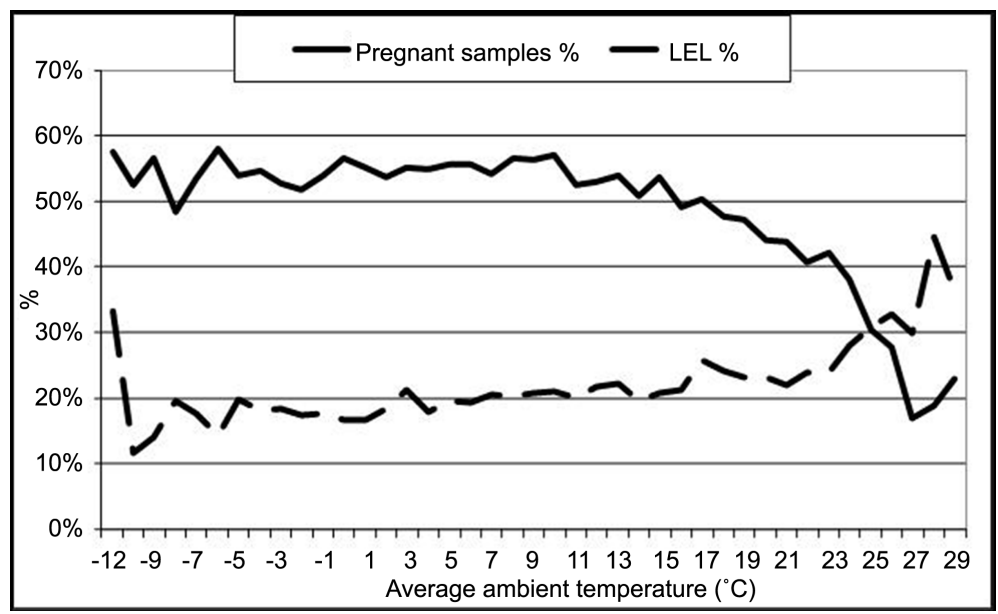

Figure 5. Relationship of the rate of pregnant samples and late embryonic losses (LEL) with ambient temperature [36].

rum carotene and plasma IGF-I concentrations were significantly lower in summer than in winter. The high plasma NEFA concentration found in summer appeared to be in association with the lower body condition score (BCS) caused by depressed appetite. Statistical analysis supports the hypothesis that increased plasma NEFA and BHB and decreased plasma IGF-I concentrations may result in reduced fertility in summer. These changes may be associated with the more frequent appearance of cystic ovarian diseases (COD, Table 3) and probably have a negative effect on ovarian function and/or oocyte quality [37].

\section{Ultrasonic Ovarian Morphology in Postpartum Cows}

Postpartum NEBAL (indicated by lower BCS as well as higher plasma NEFA and BHB levels) suppresses immune function and promotes metabolic disorders, potentially explaining relationships between infectious and noninfectious transition disorders. In postpartum dairy cows, pathologic ovarian phenomena including COD and ovulatory fluid-filled ovarian phenomena (corpus luteum with cavity and cystic corpus luteum) frequently occur. Some of these phenomena are associated with metritis, but due to the increased plasma concentrations of NEFA the possible effect of NEBAL could not be excluded either. Oocytes can accumulate fatty acids, which may 


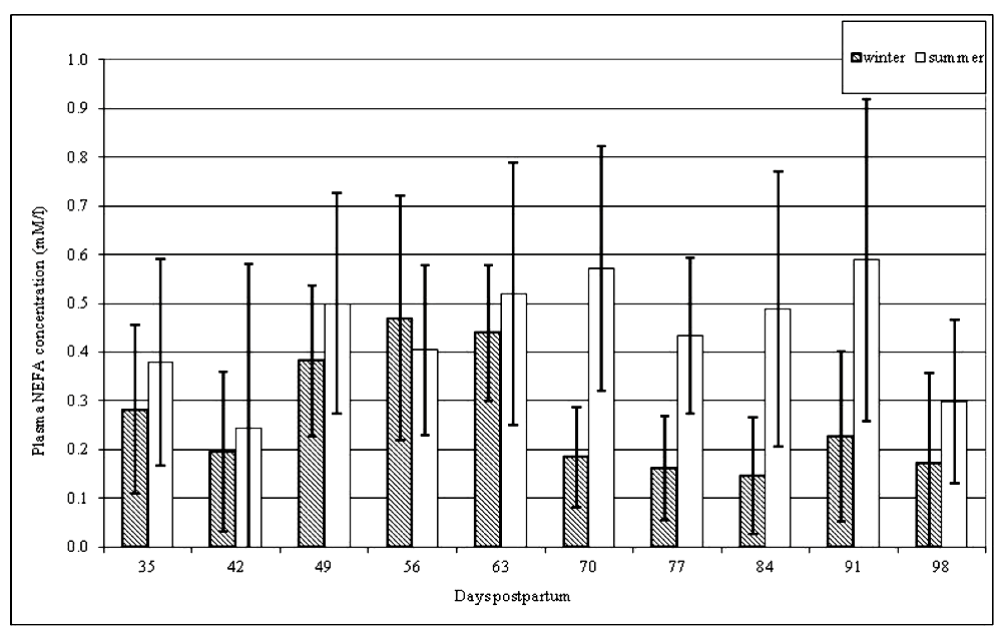

Figure 6. Plasma NEFA concentrations (mean \pm SD) in summer and winter [37].

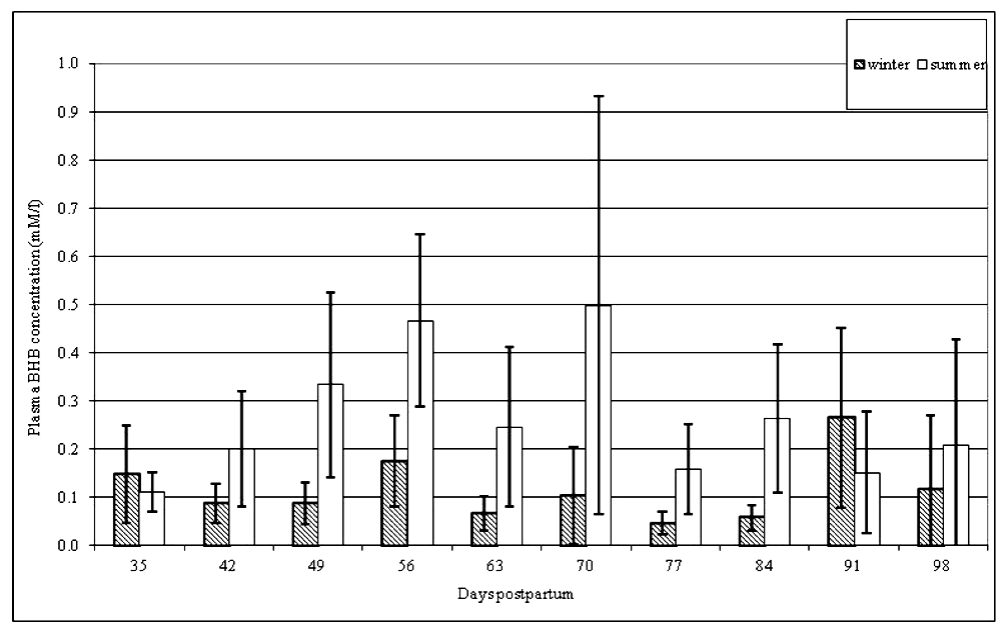

Figure 7. Plasma BHB concentrations (mean \pm SD) in summer and winter [37].

Table 3. Frequency and rate of ovulatory (ovulatory fluid-filled ovarian phenomena, OFOP) and non-ovulatory (non-ovulatory cystic ovarian phenomena, NCOP) ovarian phenomena (source: Catus database, 2008-2011).

\begin{tabular}{|c|c|c|c|c|}
\hline & 2008 & 2009 & 2010 & 2011 \\
\hline Number of ultrasound examinations & 659 & 547 & 454 & 619 \\
\hline Number of detected NCOP & 83 & 84 & 76 & 142 \\
\hline NCOP, \% & 12.6 & 15.4 & 16.7 & 22.9 \\
\hline Number of detected OFOP & 119 & 61 & 59 & 70 \\
\hline OFOP, \% & 18.1 & 11.2 & 13.0 & 11.3 \\
\hline Daily milk production $(\mathrm{kg})$ in NCOP cows & 36.9 & 37.9 & 37.9 & 38.2 \\
\hline Daily milk production $(\mathrm{kg})$ in OFOP cows & 35.9 & 36.2 & 36.1 & 37.1 \\
\hline
\end{tabular}

change their lipid content and composition. The accumulation of lipid in oocytes and embryos can reduce their quality and cryotolerance.

Ultrasound examination of dairy cows in the same Hungarian dairy herds between 2008 and 2011 showed a definite increase in the rate of non-ovulatory cystic ovarian phenomena (Table 3) in parallel with a decreased 
rate of ovulatory fluid-filled ovarian phenomena and increased milk production (Table 3).

\section{Conclusion}

Increased milk production together with suboptimal farm management (especially nutrition or reproduction) can reduce fertility. The major problem in postpartum cows is the imbalance between the body reserves and milk production. This is why a negative energy balance (NEBAL) occurs in the background and causes reduced fertility. An insufficient or imbalanced nutrient intake might lead to the malfunction of organs, causing reproductive failure. Supplementation of gluconeogenic materials (propylene glycol, glycerol, propionic acid) indirectly improves reproductive efficiency. Our recently developed databases (Catus and Bopella) provide an opportunity for analyzing relationships between the results of ultrasonic, endocrine and metabolic measurements.

\section{Acknowledgements}

This study was supported by NFÜ (National Development Agency) KMR_12-1-2012-0075 project.

\section{References}

[1] Nieuwhof, G.J., Powell, R.L. and Norman, H.D. (1989) Ages at Calving and Calving Intervals for Dairy Cattle in the United States. Journal of Dairy Science, 72, 685-692. http://dx.doi.org/10.3168/jds.S0022-0302(89)79160-8

[2] Hare, E., Norman, H.D. and Wright, J.R. (2006) Trends in Calving Ages and Calving Intervals for Dairy Cattle Breeds in the United States. Journal of Dairy Science, 89, 365-370. http://dx.doi.org/10.3168/jds.S0022-0302(06)72102-6

[3] Mészáros, G. (2012) Calving Period and Lactation in Hungarian HF Population between 2001 and 2011. Hungarian Dairy Herd Recording Ltd. Newsletter, 2001-2012.

[4] Rodriguez-Martinez, H., Hultgren, J., Båge, R., Bergqvist, A.S., Svensson, C., Bergsten, C., et al. (2008) Reproductive Performance in High-Producing Dairy Cows: Can We Sustain It under Current Practice? In: I.V.I.S., Eds., IVIS Reviews in Veterinary Medicine, International Veterinary Information Service, Ithaca NY (www.ivis.org), Last Updated: 11-Dec-2008; R0108.1208.

[5] Santschi, D.E., Lefebvre, D.M., Cue, R.I., Girard, C.L. and Pellerin, D. (2011) Economic Effect of Short (35-d) Compared with Conventional (60-d) Dry Period Management in Commercial Canadian Holstein Herds. Journal of Dairy Science, 94, 4734-4743. http://dx.doi.org/10.3168/jds.2010-3596

[6] Santschi, D.E., Lefebvre, D.M., Cue, R.I., Girard, C.L. and Pellerin, D. (2011) Incidence of Metabolic Disorders and Reproductive Performance Following a Short (35-d) or Conventional (60-d) Dry Period Management in Commercial Holstein Herds. Journal of Dairy Science, 94, 3322-3330. http://dx.doi.org/10.3168/jds.2010-3595

[7] de Feu, M.A., Evans, A.C.O., Lonergan, P. and Butler, S.T. (2009) The Effect of Dry Period Duration and Dietary Energy Density on Milk Production, Bioenergetic Status, and Postpartum Ovarian Function in Holstein-Friesian Dairy Cows. Journal of Dairy Science, 92, 6011-6022. http://dx.doi.org/10.3168/jds.2009-2374

[8] Collier, R.J., Annen-Dawson, E.L. and Pezeshki, A. (2012) Effects of Continuous Lactation and Short Dry Periods on Mammary Function and Animal Health. Animal, 6, 403-414. http://dx.doi.org/10.1017/S1751731111002461

[9] Watters, R.D., Wiltbank, M.C., Guenther, J.N., Brickner, A.E., Rastani, R.R., Fricke, P.M., et al. (2009) Effect of Dry Period Length on Reproduction during the Subsequent Lactation. Journal of Dairy Science, 92, 3081-3090. http://dx.doi.org/10.3168/jds.2008-1294

[10] Gümen, A., Keskin, A., Yilmazbas-Mecitoglu, G., Karakaya, E. and Wiltbank, M.C. (2011) Dry Period Management and Optimization of Post-Partum Reproductive Management in Dairy Cattle. Reproduction in Domestic Animals, 46, 11-17. http://dx.doi.org/10.1111/j.1439-0531.2011.01851.x

[11] Leblanc, S. (2010) Assessing the Association of the Level of Milk Production with Reproductive Performance in Dairy Cattle. Journal of Reproduction and Development, 56, S1-S7. http://dx.doi.org/10.1262/jrd.1056S01

[12] Thatcher, W.W., Santos, J.E.P. and Staples, C.R. (2011) Dietary Manipulations to Improve Embryonic Survival in cattle. Theriogenology, 76, 1619-1631. http://dx.doi.org/10.1016/j.theriogenology.2011.06.005

[13] Butler, S.T., Pelton, S.H. and Butler, W.R. (2006) Energy Balance, Metabolic Status, and the First Postpartum Ovarian Follicle Wave in Cows Administered Propylene Glycol. Journal of Dairy Science, 89, 2938-2951. http://dx.doi.org/10.3168/jds.S0022-0302(06)72566-8

[14] Chagas, L.M., Gore, P.J.S., Meier, S., Macdonald, K.A. and Verkerk, G.A. (2007) Effect of Monopropylene Glycol on Luteinizing Hormone, Metabolites, and Postpartum Anovulatory Intervals in Primiparous Dairy Cows. Journal of Dairy Science, 90, 1168-1175. http://dx.doi.org/10.3168/jds.S0022-0302(07)71603-X 
[15] Miyoshi, S., Pate, J.L. and Palmquist, D.L. (2001) Effects of Propylene Glycol Drenching on Energy Balance, Plasma Glucose, Plasma Insulin, Ovarian Function and Conception in Dairy Cows. Animal Reproduction Science, 68, 29-48. http://dx.doi.org/10.1016/s0378-4320(01)00137-3

[16] Jaskowski, J.M., Nowak, W., Mikula, R., Wlodarek, J., Kostencka, E. and Olechnowicz, J. (2011) Prevention of Negative Energy Balance in the Transition Period-Implications for Plasma Metabolites, Production and Reproduction of Cows. Medycyna Weterynaryjna, 67, 647-652.

[17] Melendez, P., Donovan, G.A., Risco, C.A., Littell, R. and Goff, J.P. (2003) Effect of Calcium-Energy Supplements on Calving-Related Disorders, Fertility and Milk Yield during the Transition Period in Cow Fed Anionic Diets. Theriogenology, 60, 843-854. http://dx.doi.org/10.1016/S0093-691X(03)00103-1

[18] Wang, C., Liu, Q., Yang, W.Z., Huo, W.J., Dong, K.H., Huang, Y.X., et al. (2009) Effects of Glycerol on Lactation Performance, Energy Balance and Metabolites in Early Lactation Holstein Dairy Cows. Animal Feed Science and Technology, 151, 12-20. http://dx.doi.org/10.1016/j.anifeedsci.2008.10.009

[19] Leon, A.O., Ceron, J.H. and Gutierrez, C.G. (2010) Glycerol Supplementation after Artificial Insemination Increases Conception Rate in Holstein Cows. Revista Mexicana de Ciencias Pecuarias, 1, 69-74.

[20] Mulliniks, J.T., Kemp, M.E., Cox, S.H., Hawkins, D.E., Cibils, A.F., VanLeeuwen, D.M., et al. (2011) The Effect of Increasing Amount of Glucogenic Precursors on Reproductive Performance in Young Postpartum Range Cows. Journal of Animal Science, 89, 2932-2943. http://dx.doi.org/10.2527/jas.2010-3198

[21] McNamara, S., Butler, T., Ryan, D.P., Mee, J.F., Dillon, P., O’Mara, F.P., et al. (2003) Effect of Offering RumenProtected Fat Supplements on Fertility and Performance in Spring-Calving Holstein-Friesian Cows. Animal Reproduction Science, 79, 45-56. http://dx.doi.org/10.1016/S0378-4320(03)00111-8

[22] Mattos, R., Staples, C.R., Arteche, A., Wiltbank, M.C., Diaz, F.J., Jenkins, T.C., et al. (2004) The Effects of Feeding Fish Oil on Uterine Secretion of $\mathrm{PGF}_{2 \alpha}$, Milk Composition, and Metabolic Status of Periparturient Holstein Cows. Journal of Dairy Science, 87, 921-932. http://dx.doi.org/10.3168/jds.S0022-0302(04)73236

[23] Fouladi-Nashta, A.A., Gutierrez, C.G., Gomg, J.G., Garnsworthy, P.C. and Webb, R. (2007) Impact of Dietary Fatty Acids on Oocyte Quality and Development in Lactating Dairy Cows. Biology of Reproduction, 77, 9-17. http://dx.doi.org/10.1095/biolreprod.106.058578

[24] Boken, S.L., Staples, C.R., Sollenberger, L.E., Jenkins, T.C. and Thatcher, W.W. (2005) Effect of Grazing and Fat Supplementation on Production and Reproduction of Holstein Cows. Journal of Dairy Science, 88, 4258-4272. http://dx.doi.org/10.3168/jds.S0022-0302(05)73112-X

[25] Caldari-Torres, C., Lock, A.L., Staples, C.R. and Badinga, L. (2011) Performance, Metabolic, and Endocrine Responses of Periparturient Holstein Cows Fed 3 Sources of Fat. Journal of Dairy Science, 94, 1500-1510. http://dx.doi.org/10.3168/jds.2010-3748

[26] Silvestre, F.T., Carvalho, T.S.M., Francisco, N., Santos, J.E.P., Staples, C.R., Jenkins, T.C., et al. (2011) Effects of Differential Supplementation of Fatty Acids during the Peripartum and Breeding Periods of Holstein Cows: I. Uterine and Metabolic Responses, Reproduction, and Lactation. Journal of Dairy Science, 94, 189-204. http://dx.doi.org/10.3168/jds.2010-3370

[27] Hayirli, A. (2006) The Role of Exogenous Insulin in the Complex of Hepatic Lipidosis and Ketosis Associated with Insulin Resistance Phenomenon in Postpartum Dairy Cattle. Veterinary Research Communications, 30, 749-774. http://dx.doi.org/10.1007/s11259-006-3320-6

[28] Nielsen, N.I. and Ingvartsen, K.L. (2004) Propylene Glycol for Dairy Cows: A Review of the Metabolism of Propylene Glycol and Its Effects on Physiological Parameters, Feed Intake, Milk Production and Risk of Ketosis. Animal Feed Science and Technology, 115, 191-213. http://dx.doi.org/10.1016/j.anifeedsci.2004.03.008

[29] Defrain, J.M., Hippen, A.R., Kalscheur, F. and Jardon, P.W. (2004) Feeding Glycerol to Transition Dairy Cows: Effects on Blood Metabolites and Lactation Performance. Journal of Dairy Science, 87, 4195-4206. http://dx.doi.org/10.3168/jds.S0022-0302(04)73564-X

[30] Linke, P.L., Defrain, J.M., Hippen, A.R. and Jardon, P.W. (2004) Ruminal and Plasma Responses in Dairy Cows to Drenching or Feeding Glycerol. Journal of Dairy Science, 87, 343.

[31] Hightshoe, R.B., Cochran, R.C., Corah, L.R., Kiracofe, G.H., Harmon, D.L. and Perry, R.C. (1991) Effects of Calcium Soaps of Fatty Acids on Postpartum Reproductive Function in Beef Cows. Journal of Animal Science, 69, 4097-4103.

[32] Lucy, M.C., Staples, C.R., Michel, F.M. and Thatcher, W.W. (1991) Effect of Feeding Calcium Soaps to Early Postpartum Dairy Cows on Plasma PGF2 $\alpha$, Luteinizing Hormone, and Follicular Growth. Journal of Dairy Science, 74, 483-489. http://dx.doi.org/10.3168/jds.S0022-0302(91)78195

[33] Sklan, D., Moallem, U. and Folman, Y. (1991) Effect of Feeding Calcium Soaps of Fatty Acids on Production and Reproductive Responses in High Producing Lactating Cows. Journal of Dairy Science, 74, 510-517. http://dx.doi.org/10.3168/jds.S0022-0302(91)78198-8 
[34] Scott, T.A., Shaver, R.D., Zepeda, L., Yandell, B. and Smith, T.R. (1995) Effects of Rumen-Inert Fat on Lactation, Reproduction, and Health of High Producing Holstein Herds. Journal of Dairy Science, 78, 2435-2451. http://dx.doi.org/10.3168/jds.S0022-0302(95)76872-2

[35] Spears, J.W. and Weiss, W.P. (2008) Role of Antioxidants and Trace Elements in Health and Immunity of Transition Dairy Cows. The Veterinary Journal, 176, 70-76. http://dx.doi.org/10.1016/j.tvjl.2007.12.015

[36] Gábor, G. and Balogh, O.G. (2010) Factors Influencing Pregnancy Rate in Dairy Cattle. Proceedings of the International Strategic Programs for Conservation of Genetic Resources for Food and Agriculture OECD Workshop, Vancouver, 17 July 2010, 78-83.

[37] Balogh, O.G., Febel, H., Huszenicza, G., Kulcsar, M., Abonyi-Toth, Z., Endrodi, T., et al. (2012) Seasonal Fertility Differences in Synchronised Dairy Cows: Ultrasonic, Metabolic and Endocrine Findings. Acta Veterinaria Hungarica, 60, 131-143. http://dx.doi.org/10.1556/AVet.2012.011

\section{Abbreviation Note}
AI-Artificial insemination
BCS-Body condition score
BHB-Beta-hidroxy butyrate
COD_Cystic ovarian diseases
DMI-Dry matter intake
FA-Fatty acid
FO_Calcium salts of fish oil
LCFA-Calcium-long chain fatty acid
LEL-Late embryonic loss
LH-Luteinizing hormone
NEBAL_-Negative energy balance
NEFA - Non-esterified fatty acid
P4-Progesterone
$\mathrm{PGE}_{2}$-Prostaglandin $\mathrm{E}_{2}$
$\mathrm{PGF}_{2 \alpha}$-Prostaglandin $\mathrm{F}_{2 \alpha}$
PGFM-PGF $2 \alpha$ metabolite
PGL-Propylene glycol
PSPB_-Pregnancy-specific protein B
PUFA - Polyunsaturated fatty acids
RFM-Retained fetal membranes
RPS - Rate of pregnant samples
$\mathrm{SO}$-Calcium salts of safflower oil
SORB-Soybean oil refining by-products 